ISSN : 2303-1514 | E-ISSN : 2598-5949

\title{
THE EFFECT OF PROBLEM BASED LEARNING AND THINK PAIR SHARE BASED ON BLENDED LEARNING ON MATHEMATICS LEARNING OUTCOMES
}

\author{
Sugiyanti $^{1}$, Murtono ${ }^{2}$, Sri Surachmi $\mathbf{W}^{3}$ \\ ${ }^{1,2,3}$ Program Studi S2 PGSD, Universitas Muria Kudus, Indonesia \\ *1sugiyanti030@gmail.com
}

\section{PENGARUH PROBLEM BASED LEARNING DAN THINK PAIR SHARE BERBASIS BLENDED LEARNING TERHADAP HASIL BELAJAR MATEMATIKA}

\begin{tabular}{|c|c|}
\hline ARTICLE HISTORY & ABSTRACT \\
\hline $\begin{array}{l}\text { Submitted: } \\
\text { 18 Juli 2021 } \\
18^{\text {th }} \text { July } 2021\end{array}$ & $\begin{array}{l}\text { Abstract: The COVID-19 pandemic has changed the learning system in Indonesia from face-to- } \\
\text { face learning to distance. Such changes in the learning system need to be addressed with the } \\
\text { use of learning models that are in accordance with the current distance learning system. } \\
\text { Blended learning is a learning approach that combines face-to-face and online learning as an } \\
\text { alternative to this changing learning system. This study aimed to determine the effect of the } \\
\text { model on problem based learning (PBL) and think pair share (TPS) based on blended learning } \\
\text { on students' mathematics learning outcomes and knowing the differences in learning outcomes } \\
\text { between-based PBL and TPS models model blended learning. This study utilized quantitative } \\
\text { research by comparing two learning models to students' mathematics learning outcomes. The } \\
\text { research sample was from sixth grade students of SD N Mojo } 1 \text { and SD N Trengguli } 3 \text { in } \\
\text { Kabupaten Demak. The results showed that the PBL model based on blended learning had an } \\
\text { effect of } 80.5 \% \text { on students' learning outcomes, the TPS model based on blended learning had } \\
\text { an effect of } 71.9 \% \text { on students' learning outcomes, and both models had no difference on the } \\
\text { students' learning outcomes. This showed that the blended learning approach in the PBL and } \\
\text { TPS models significantly influenced students' mathematics learning outcomes. }\end{array}$ \\
\hline
\end{tabular}

Accepted:

15 September 2021

$15^{\text {th }}$ September 2021

Published:

27 Oktober 2021

$27^{\text {th }}$ October 2021
Keywords: PBL, TPS, Blended learning, mathematics learning outcomes

Abstrak: Pandemi covid-19 mengubah sistem pembelajaran di Indonesia dari pembelajaran tatap muka menjadi pembelajaran jarak jauh. Perubahan sistem pembelajaran yang demikian perlu disikapi dengan penggunaan model pembelajaran yang sesuai dengan sistem pembelajaran jarak jauh. Blended learning merupakan pendekatan pembelajaran yang memadukan pembelajaran tatap muka dan daring sebagai alternatif dari perubahan sistem pembelajaran ini. Penelitian ini bertujuan untuk mengetahui adanya pengaruh model problem based learning $(P B L)$ dan think pair share (TPS) berbasis blended learning terhadap hasil belajar matematika siswa dan mengetahui adanya perbedaan hasil belajar antara model PBL dan TPS berbasis blended learning. Penelitian kuantitatif dengan membandingkan dua model pembelajaran terhadap hasil belajar matematika siswa. Sampel penelitian dari siswa kelas VI SD N Mojo 1 dan SD N Trengguli 3 di Kabupaten Demak. Hasil penelitian yang diperoleh bahwa model PBL berbasis blended learning berpengaruh sebesar $80.5 \%$ terhadap hasil belajar siswa, model TPS berbasis blended learning berpengaruh sebesar $71.9 \%$ terhadap hasil belajar siswa, dan tidak adanya perbedaan hasil belajar siswa pada model PBL berbasis blended learning dengan model TPS berbasis blended learning. Hal ini menunjukan bahwa pendekatan blended learning pada model PBL dan TPS secara signifikan berpengaruh terhadap hasil belajar matematika siswa.memberikan gambaran mengenai penelitian yang dilaksanakan, ditulis lengkap dan jelas.

Kata Kunci: PBL, TPS, blended learning, hasil belajar matematika

\section{CITATION}

Sugiyanti, S., Murtono, M., \& W. Surachmi, S. (2021). The Effect of Problem Based Learning and Think Pair Share Based on Blended Learning on Mathematics Learning Outcomes. Jurnal Pendidikan Guru Sekolah Dasar, 10 (5), 1175-1181. DOI: http://dx.doi.org/10.33578/jpfkip.v10i5.8487. 


\section{PENDAHULUAN}

Perubahan sistem pembelajaran di Indonesia dari pembelajaran tatap muka menjadi pembelajaran daring akibat pandemi covid-19, hal ini perlu adanya perubahan penggunaan model pembelajaran yang dilakukan dalam pembelajaran di era pandemi ini. Menurut menteri pendidikan dan kebudayaan "Pembelajaran jarak jauh, ini akan menjadi permanen. Bukan pembelajaran jarak jauh pure saja, tapi hybrid model". Dalam pembelajaran jarak jauh ini perlu adanya pemanfaatan teknologi dalam kegiatan belajarmengajar akan menjadi hal yang mendasar. Pendidikan sekarang yang memang membutuhkan perubahan dalam pembelajaran, perlu adanya pengembangan tekhnologi dalam mendorong proses belajar mengajar menjadi lebih menyenangkan dan efektif sehingga dapat meningkatkan hasil belajar siswa. Salah satu pendeketan pembelajaran yang memadukan tekhnologi berbasis daring dan tatap muka adalah blended learning. Pembelajaran yang konsep baru dalam penyampaian materi dapat dilakukan di kelas dan online (Husamah, 2014), pendekatan pembelajaran blended learning dapat membantu menyesuaikan model pembelajaran yang digunakan dalam praktek pembelajaran di era pandemi covid-19. Selain itu diperlukan juga model pembelajaran yang menekankan pada keefektivan siswa dalam belajar agar potensi yang dimilikinya berkembang maksimal.

Model pembelajaran yang memiliki karakteristik seperti itu adalah model problem based learning (PBL) yang diasumsikan dapat mengatasi permasalahan pembelajaran tersebut. Menurut Cazzola (2008: 1), problem based learning adalah pembelajaran berpusat pada siswa yang didasarkan pada analisis, resolusi, dan diskusi tentang masalah yang diberikan. Dengan pengembangan ilmu tekhnologi sehingga dapat meningkatkan efektivitas model pembelajaran problem based learning yang digunakan dalam pembelajaran campuran atau Blended Learning merupakan program pendidikan formal yang memungkinkan siswa belajar paling tidak sebagian melalui konten dan petunjuk yang disampaikan secara daring dengan kendali mandiri terhadap waktu, tempat, urutan, maupun kecepatan belajar (Staker, 2012).

Pengunaan model lain yang sesuai dengan pembelajaran blended learning dengan mempertimbangkan keefektifan dari pembelajaran yang akan dilakukan dalam pembelajaran ditengah pandemic ini adalah model pembelajaran Think-Pair-Share (TPS). Model ini memberikan kepada siswa waktu untuk berpikir dan merespons serta saling membantu satu sama lain, sehingga partisipasi pembelajaran blended learning siswa lebih optimal. Menurut Trianto (2007: 61-62) ThinkPair-Share (TPS) pertama kali dikembangkan oleh Frang Lyman dan koleganya di Universitas Maryland. Resiko dalam pembelajaran TPS relatif rendah dan struktur pembelajaran kolaboratif pendek, sehingga sangat ideal bagi guru dan siswa yang baru belajar kolaboratif, TPS merupakan jenis pembelajaran kooperatif yang dirancang untuk mempengaruhi pola interaksi siswa.

\section{KAJIAN TEORI}

Model pembelajaran problem based learning (PBL) dan think pair share (TPS) dipadukan dengan blended learning digunakan dalam pelaksanaan pembelajaran untuk pembelajaran jarak jauh dan tatap muka. Problem based learning merupakan pembelajaran yang melibatkan siswa dalam memecahkan masalah dengan mengintegrasikan berbagai konsep dan keterampilan dari berbagai disiplin ilmu (Komalasari, 2013). Pendekatan PBL menjanjikan dalam mengatasi tantangan dunia nyata, keterampilan berpikir tingkat tinggi, keterampilan komunikasi, keterampilan pemecahan masalah dan pembelajaran mandiri (Shisigu, 2017), hal ini menjadikan pembelajaran PBL model pembelajaran yang menggunakan masalah dunia nyata sebagai suatu konteks bagi siswa untuk belajar 
memecahkan masalah, serta untuk memperoleh pengetahuan dan konsep yang esensial dari materi

pembelajaran dengan cara mereka sendiri / belajar mandiri. Pembelajaran TPS bisa membuat siswa untuk berfikir sendiri dan berdiskusi dengan temannya, serta dapat menumbuhkan partisipasi siswa (Jumanta, 2014). Pembelajaran TPS teknik yang berpusat pada peserta didik yang memberikan siswa dengan tugas atau pertanyaan dan memberi mereka waktu untuk berpikir secara individu, kemudian berbagi pandangan mereka secara berpasangan dan akhirnya berbagi dengan kelas yang lebih besar (Johnbosco dan Okigbo, 2017). Model TPS merupakan pembelajaran yang menuntut siswa agar dapat belajar secara mandiri dan juga belajar dalam sebuah team yang harus bekerja sama menyelesaikan sebuah permasalahan yang disajikan guru di dalam kelas.

Dari beberapa penelitian mengenai blended learning (Khoiroh, 2017) motivasi siswa dalam mengikut pembelajaran blended learning lebih tinggi dibandingkan dengan hasil belajar siswa menggunakan model pembelajaran langsung atau tatap muka. (Wardani, 2018) Dengan blended learning interaksi dan komunikasi antar siswa dan antara guru dan siswa dapat terus berlangsung dan hal tersebut merupakan daya tarik pembelajaran di era 21. Blended learning merupakan pembelajaran yang dapat mengatisipasi kelemahan pada pembelajaran jarak jauh yang dipadukan dengan model pembelajaran PBL dan TPS. Kedua model yang digunakan berbasis blended learning membuat masing-masing model pembelajaran ini menjadi model yang saling mengisi dari segi kelemahan dan kelebihan yang ada.

Penelitian ini bertujuan untuk mengetahui adanya pengaruh model problem based learning (PBL) dan think pair share (TPS) berbasis blended learning terhadap hasil belajar matematika siswa dan untuk mengetahui adanya perbedaan hasil belajar antara model PBL dan TPS berbasis blended learning. Penelitian ini untuk membantu guru dalam menentukan model pembelajaran yang akan digunakan dalam pembelajaran di era pandemi covid-19 dan dapat meningkatkan hasil belajar siswa.

\section{METODE PENELITIAN}

Penelitian ini merupakan penelitian kuantitatif. Menurut sugiyono (2015:7), Data penelitian pada pendekatan kuantitatif berupa angka-angka dan analisis menggunakan statistic. Penelitian ini menggunakan penelitian kuantitatif karena gejala yang diamati dapat diukur dan diubah dalam bentuk angka sehingga memungkinkan digunakannya analisis statistic. Untuk melihat pengaruh dari model problem based learning dan think pair share berbasis blended learning terhadap hasil belajar matematika siswa dan melihat adanya perbedaan hasil belajar antara model PBL dan TPS berbasis blended learning.

Penelitian ini mengunakan desain penelitian eksperimen, dengan mengambil 2 kelas ekperimen, kelas eksperimen 1 (pembelajaran dengan model pembelajaran problem based learning berbasis blended learning), kelas ekperimen 2 (pembelajaran dengan model pembelajaran think pair share berbasis blended learning). Desain penelitian yang digunakan dalam penelitian ini berupa desain pretest-posttest dengan perlakuan eksperimen 1 (X1) dan eksperimen 2 (X2). Penelitian ini dilakukan pada semester genap tahun ajaran 2020/2021 dengan subyek penelitian siswa kelas VI, SD Mrisen 1, SD N Mojo 1 dan SD N Trengguli 3 di Kabupaten Demak. Teknik pengambilan sampel dengan menggunakan teknik simple random sampling. Data yang akan diteliti berasal dari mengamati aktivitas langkah atau syntak model pembelajaran PBL dan TPS berbasis blended learning yang dilakukan siswa dan hasil belajar masing-masing model pembelajaran PBL dan TPS berbasis blended learning.

Analisis data dilakukan untuk menguji hipotesa dalam rangka penarikan kesimpulan mencapai tujuan penelitian, dibagi dalam dua 
tahap, yaitu tahap awal yang merupakan tahap sampel dan tahap akhir yang merupakan tahap analisis data untuk menguji hipotesis penelitian. Prosedur dalam penelitian ini pertama melihat hasil belajar pre-test pada setiap kelas eksperimen 1 kelas dengan perlakuan model PBL berbasis blended learning dan kelas eksperimen 2 dengan perlakuan model TPS berbasis blended learning. Nilai hasil belajar kemampuan pretest kelas eksperimen 1 dan eksperimen 2 akan dilihat normalitas dan homogenitas kedua kelas eksperimen tersebut. Pada tahap membuktikan hipotesis pertama dan kedua, peneliti melihat nilai post-test hasil belajar kedua kelas eksperimen dan hasil pengamatan langkah pembelajaran pada kedua kelas eksperimen, selanjutnya peneliti menghubungkan pengaruh langkah model pembelajaran yang diamati pada kelas eksperimen 1 dan eksperimen 2 terhadap hasil belajar siswa, pembuktian hipotesis dengan menggunakan uji analisis regresi. Perbedaan hasil belajar pada kedua kelas ekperimen dapat dilihat dari rata-rata hasil belajar matematika dengan pembuktian hipotesis dengan menggunakan anlisis uji $\mathrm{t}$ dua pihak.

\section{HASIL DAN PEMBAHASAN}

Hipotesis pertama diuji dengan menggunakan uji regresi linear sederhana berdasarkan analisis data diketahui bahwa nilai $\mathrm{F}_{\text {hitung }}=107.582$ dan nilai Sig $\mathrm{F}=0.00$. Dari tabel nilai $\mathrm{F}_{\text {tabel }}$ dengan nilai $\alpha=0.05 \mathrm{n}=28$ maka nilai $F_{\text {tabel }}=3.34$. Dari hasil tersebut diperoleh $\mathrm{F}_{\text {hitung }}>\mathrm{F}_{\text {tabel }}$ artinya Ho ditolak sehingga dapat disimpulkan bahwa terdapat pengaruh signifikan pembelajaran model problem based learning berbasis blended learning terhadap hasil belajar matematika siswa kelas VI SD. Sementara besar pengaruh yang diberikan variabel pembelajaran model problem based learning adalah 0.805 atau $80.5 \%$ yang berarti bahwa variabel pembelajaran model problem based learning berbasis blended learning berpengaruh sebesar $80.5 \%$ terhadap hasil belajar matematika siswa kelas VI SD. Pengaruh yang signifikan ini tentu karena pembelajaran ini memadukan pembelajaran yang tersedia pada masa pandemic Covid-19 yaitu pembelajaran berbasis blended learning karena pembelajaran ini memadukan antara pembelajaran tatap muka dan pembelajaran online tentu sesuai dengan sistem pendidikan yang terjadi saat ini. Dengan adanya blended learning yang memiliki keunggulan pada pembelajaran tatap muka dan dipadukan keunggulan pada pembelajaran online.

Hipotesis kedua melihat pengaruh kelas eksperimen 2 terhadap hasil belajar siswa dengan menggunakan analisis regresi sederhana diketahui bahwa nilai $\mathrm{F}_{\text {hitung }}=$ 71.502 dan nilai Sig $F=0.000$. Dari tabel nilai $\mathrm{F}_{\text {tabel }}$ dengan nilai $\alpha=0.05 \mathrm{n}=30$ maka nilai $\mathrm{F}_{\text {tabel }}=3.32$. Dari hasil tersebut diperoleh $\mathrm{F}_{\text {hitung }}$ $>\mathrm{F}_{\text {tabel }}$ artinya Ho ditolak sehingga dapat disimpulkan terdapat pengaruh signifikan pembelajaran model think paire share berbasis blended learning terhadap hasil belajar matematika siswa kelas VI SD. Sementara besar pengaruh yang diberikan variabel pembelajaran model think paire share adalah 0.719 yang berarti bahwa variabel pembelajaran model problem based learning berbasis blended learning berpengaruh sebesar $71.9 \%$ terhadap hasil belajar matematika siswa kelas VI SD. Terbuktinya pengaruh model think paire share berbasis blended learning karena pembelajaran yang dilakukan dapat menyelesaikan permasalahan yang dihadapi siswa dengan memberikan waktu berfikir untuk siswa menjawab pertanyaan yang didapatkan kemudian mendiskusikan dengan interaksi antar kelompok teman terdekat, dilanjutkan dengan membagikan penyelesaian permasalahan yang dihadapi masing masing kelompok. Dengan pembelajaran yang berarah pada kooperatif learning, pembelajaran think paire share ini masing-masing anggota kelompok saling membantu dalam memperoleh konsep materi lingkaran kelas VI SD. 
Hipotesis ketiga adalah melihat ada perbadaan hasil belajar siswa pada pembelajaran model problem based learning berbasis blended learning dan model think paire share berbasis blended learning. diperoleh bahwa nilai $t_{\text {hitung }}=1.741$ sedangkan sig 2 tailed $=0.087$ dengan taraf signifikansi 0.05 dengan perhitungan $t_{\text {tabel }}=2.00$ dengan $n$ $=56, \alpha=0.05$. Sehingga nilai yang didapatkan $-\mathrm{t}_{\text {tabel }}<\mathrm{t}_{\text {hitung }}<\mathrm{t}_{\text {tabel }}$ atau $-2.00<1.741<2.00$ dan nilai sig $0.087>0.05$ maka dapat disimpulkan Ho diterima dapat disimpulkan bahwa tidak adanya perbedaan hasil belajar model pembelajaran problem based learning berbasis blended learning dan model pembelajaran think pair share berbasis blended learning

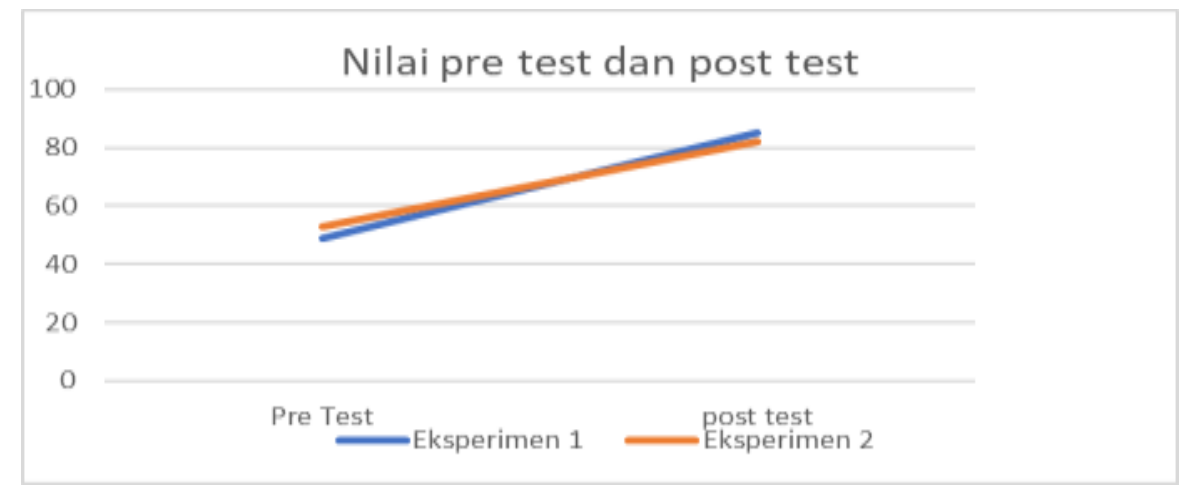

Gambar 1. Nilai Pre Test dan Post Test kelas Eksperimen 1 dan 2

Tidak adanya perbedaan hasil belajar pada kelas eksperimen 1 dan eksperimen 2 karena pembelajaran yang dilakukan samasama mengunakan pembelajaran berbasis blended learning. Pembelajaran ini merupakan pembelajaran yang sering diupayakan dalam Pendidikan di massa pandemic covid 19 karena sistem Pendidikan Indonesia yang berubah menjadi sistem pembelajaran jarak jauh dengan blended learning peneliti mengkombinasikan tatap muka dan virtual atau pembelajaran daring untuk meningkatkan hasil belajar siswa.

Dalam analisis deskriptif terdapat sedikit perbedaan antara kedua kelas eksperimen tersebut. Hal ini terlihat pada tabel dibawah ini:

Tabel 1. Tabel Perbedaan Peningkatan Gain

\begin{tabular}{lccccc}
\hline No. & Kelas & $\begin{array}{c}\text { Rata-Rata Pre } \\
\text { test }\end{array}$ & $\begin{array}{c}\text { Rata-Rata } \\
\text { Post Test }\end{array}$ & N-Gain & Kategori \\
\hline 1 & Eksperimen 1 & 49.107 & 84.893 & 0.703 & Tinggi \\
2 & Eksperimen 2 & 52.667 & 81.800 & 0.615 & Sedang \\
\hline
\end{tabular}

Perbedaan rata-rata hasil belajar kelas eksperimen 1 dan eksperimen 2 dikarenakan pada pembelajaran problem based learning berbasis blended learning siswa diajak mengkonstruksi pemahaman mereka sendiri mengenai konsep lingkaran, sehingga anak menjadi lebih bermakna dalam belajar. Sedangkan pembelajaran think paire share hanya mengandalkan diskusi dengan anggota kelompok yang ada. Pada saat proses diskusi anggota kelompok secara daring beberapa kelompok tidak dalam kelompok yang heterogen, sulitnya membentuk kelompok heterogen pada pembelajaran masa pandemi ini. Kelompok diskusi yang tidak heterogen ini menjadikan beberapa anak kurang memahami konsep lingkaran. Sehingga hasil belajar yang 
diperoleh tidak mendapatkan nilai yang maksimal.

Pembelajaran yang dilakukan model problem based learning berbasis blended learning pembelajaran ini mengkontruksikan permasalahan yang diberikan guru kedalam penyelidikan mereka untuk mengembangkan hasil karya mereka sendiri-sendiri jadi konsep materi lingkaran dapat ditemukan oleh masingmasing siswa, sehingga konsep materi lingkaran melekat kedalam pikiran siswa dan tidak mudah lupa. Setelah konsep yang ditemukan siswa sendiri terbentuk siswa menganalisis pemecahan masalah pada permasalahan yag mereka hadapi sehingga belajar menjadi lebih bermakna. Dengan berbasis blended learning siswa juga lebih mudah mengaskses pembelajaran mereka kembali dengan tayangan-tayangan saat pembelajaran online. Hal ini mengakibatkan lebih mudahnya siswa dalam mengerjakan soal permasalahan yang dihadapi karena sudah terbiasa mengkonstruksi pemahaman mereka sendiri yang berujung pada peningkatan hasil belajar matematika siswa kelas VI SD. Sedangkan pembelajaran yang berarah pada kooperatif learning yaitu pada pembelajaran think paire share ini masing-masing anggota kelompok saling membantu dalam memperoleh konsep materi lingkaran kelas VI SD. Konsep yang didapatkan berasal dari pikiran masing-masing anak yang kemudian dibagikan ke dalam kelompok yang lebih luas. Bantuan kelompok memungkinkan siswa dalam belajar untuk menyelesaikan masalah, tentunya dengan pembelajaran berbasis blended learning dapat membantu siswa dalam menyelesaikan masalah dengan memberikan pembelajaran online di masa pandemic covid 19, seperti video pembelajaran dari youtube yang membuat siswa lebih memahami konsep materi lingkaran, tentu dengan bantuan anggota kelompok lain jika salah satu anggota tidak mengerti konsep yang diberikan. Tidak adanya perbedaan hasil belajar hasil belajar pada pembelajaran problem based learning dan pembelajaran Think Paire Share Hal ini terjadi karena pembelajaran yang dilakukan sama-sama mengunakan pembelajaran berbasis blended learning. Pembelajaran ini merupakan pembelajaran yang sering diupayakan dalam Pendidikan di massa pandemic covid 19 karena system Pendidikan Indonesia mengkombinasikan tatap muka dan virtual atau pembelajaran daring.

\section{SIMPULAN DAN REKOMENDASI}

Berdasarkan hasil dan pembahasan penelitan dapat disimpulkan bahwa terdapat pengaruh yang signifikan pembelajaran model PBL dan model TPS berbasis blended learning terhadap hasil belajar matematika siswa kelas VI Sekolah Dasar. Serta tidak adanya perbedaan hasil belajar siswa pada pembelajaran model problem based learning berbasis blended learning dengan pembelajaran model think pair share berbasis blended learning.

Peneliti menyarankan penggunaan model pembelajaran problem based learning berbasis blended learning dapat membantu siswa dalam mengkonstruksi pemahaman konsep mereka sendiri sehingga pembelajaran lebih bermakna. Perlu adanya penelitian lanjutan mengenai beberapa model pembelajaran yang dipadukan dengan blended learning untuk meningkatkan hasil belajar siswa, sehingga dalam pembelajaran yang sesungguhnya sebagai seorang guru dapat memilih model pembelajaran yang sesuai pada massa pandemi covid 19.

\section{DAFTAR PUSTAKA}

Hamdayama, J. (2014). Model dan Metode Pembelajaran Kreatif dan Berkarakter. Bogor: Ghalia Indonesia.

Handayani, R. D. (2017). Pengaruh Model Pembelajaran Kooperatif Tipe Think Pair Share Terhadap Hasil Belajar PKn Siswa Di Kelas IV MI Terpadu Muhammadiyah Sukarame Bandar Lampung. Jurnal Pendidikan dan Pembelajaran Dasar, 4(2), 107 - 123. 
Haruehansawasin, S. \& Kiattikomol, P. (2017). Scaffolding in problembased learning for low-achieving learners. The Journal of Educational Research, 2. 111-116.

Johnbosco, O., \& Okigbo. (2017). Effects of Think Pair Share Instructional Strategy and Gender on Secondadry Scholl Students Achievement in Computer Studies. South Eastern Journal, 5(3), 37-45.

Kumar, R. \& Refaei, B. (2017). ProblemBased Learning Pedagogy Fosters Students' Critical Thinking About Writing. Interdisciplinary Journal of Problem-Based Learning, 11(2). 21 26.

Komalasari, K. (2013). Pembelajaran Kontekstual Konsep dan Aplikasi. Bandung: Refika Aditama.

Khoiroh, N. (2017). Pengaruh Model Pembelajaran Blended Learning dan Motivasi Belajar Terhadap Hasil Belajar Siswa. Jurnal Penelitian Ilmu Pendidikan, 10 (2), 97-110.

Offiah, F. C. \& Okonkwo, C. O. (2011). Cooperative learning strategy and students' academic achievement in chemistry. UNIZIK Journal of STM Education, 1(2), 63-70.

Prahmana, A. G. (2016). Pengaruh Model Problem Based Learning (PBL) Terhadap Hasil Belajar Dan Keterampilan Proses Sains Dalam Pembelajaran Fisika di SMA. UNEJ, 5(1), 129-134.

Raditya, I. W. (2015). Pengaruh Model Pembelajaran Kooperatif Tipe Think Pair Share (TPS) Terhadap Hasil Belajar IPA Siswa Kelas VI SD Gugus Letda Made Putra Kecamatan Denpasar Utara Tahun Ajaran 2014/2015. Jurnal Mimbar PGSD Universitas Pendidikan Ganesha, 3, 20-35.

Shisigu, A., \& Zerihun, A. (2017). ProblemBased Learning and Conceptual Understanding of College Female Students in Physics. EURASIA Journal of Mathematics, 14(1), 145-154.

Tirtarahardja, U. (2005). Pengantar Pendidikan. Bandung: Rineka Cipta.

Widiara, I. K. (2018). Blended Learning Sebagai Alternatif Pembelajaran di Era Digital. Jurnal Purwadita, 2(2), 50-56. 